\title{
Comment on the Evaluation of the Effectiveness of Hyaluronidase in the Selective Nerve Root Block of Radiculopathy
}

\author{
Laxmaiah Manchikanti $^{1,2}$, Alan David Kaye ${ }^{3}$ \\ ${ }^{1}$ Pain Management Center of Paducah, Paducah, KY, USA \\ ${ }^{2}$ Clinical Professor, Anesthesiology and Perioperative Medicine, University of Louisville, Louisville, KY, USA \\ ${ }^{3}$ Department of Anesthesia, LSU Health Science Center, New Orleans, LA, USA
}

Dear Editor,

Ko et al. [1] provided valuable information in a doubleblind, randomized, controlled clinical trial that assessed the effectiveness of hyaluronidase in selective nerve root block for radiculopathy. They included 126 patients in each group that receiving hyaluronidase or local anesthetic and steroids without hyaluronidase. A transforaminal epidural injection with a particulate steroid, along with hyaluronidase was done. Even though the results were reportedly superior in the hyaluronidase group, the follow-up was short and the proportion of patients with significant improvement was not reported. The authors discussed the adverse consequences of hyaluronidase but did not discuss the adverse consequences of particulate steroids and transforaminal epidural injections $[2,3]$. Short-term follow-up data are difficult to interpret in spine management. More recently, clinical investigators have ruled out short-term follow-ups as not being decisive, yet have utilized them to show the lack of effectiveness of interventions $[4,5]$. Consequently, the efficacy and superiority of transforaminal epidural injections continues to be debated [6-8].
The authors described that selective nerve root blocks routinely provided short-term relief. They also referenced studies reporting that selective nerve root blocks in patients with herniated intervertebral discs were effective after 2 weeks, but did not have a lasting effect $[9,10]$. Neither of the cited studies included selective nerve root blocks as part of their trials. Rather they studied interlaminar epidural injections.

Thus, the authors may want to look at various issues related to transforaminal epidural injections with its adverse consequences and recent warnings of particulate steroids, alternate techniques, and long-term outcomes of transforaminal epidural injections. It will be interesting to see if hyaluronidase is any more effective than steroids or local anesthetic alone on a long-term basis. If a methodology of at least one year had been utilized, this important research would have had greater strength and value to the medical community.

\section{Conflict of Interest}

No potential conflict of interest relevant to this article was reported.

Received May 4, 2015; Accepted May 4, 2015

Corresponding author: Laxmaiah Manchikanti

Pain Management Center of Paducah, 2831 Lone Oak Road, Paducah, Kentucky 42003, USA

Tel: +1-270-554-8373 ext. 101, Fax: +1-270-554-8987, E-mail: drlm@thepainmd.com 


\section{References}

1. Ko SB, Vaccaro AR, Chang HJ, Shin DY. An evaluation of the effectiveness of hyaluronidase in the selective nerve root block of radiculopathy: a double blind, controlled clinical trial. Asian Spine J 2015; 9:83-9.

2. Atluri S, Glaser SE, Shah RV, Sudarshan G. Needle position analysis in cases of paralysis from transforaminal epidurals: consider alternative approaches to traditional technique. Pain Physician 2013;16:321-34.

3. Rathmell JP, Benzon HT, Dreyfuss P, et al. Safeguards to prevent neurologic complications after epidural steroid injections: consensus opinions from a multidisciplinary working group and national organizations. Anesthesiology 2015;122:974-84.

4. Friedly JL, Comstock BA, Turner JA, et al. A randomized trial of epidural glucocorticoid injections for spinal stenosis. N Engl J Med 2014;371:11-21.

5. Manchikanti L, Candido KD, Kaye AD, et al. Randomized trial of epidural injections for spinal stenosis published in the New England Journal of Medicine: further confusion without clarification. Pain
Physician 2014;17:E475-88.

6. Manchikanti L, Cash KA, Pampati V, Falco FJ. Transforaminal epidural injections in chronic lumbar disc herniation: a randomized, double-blind, activecontrol trial. Pain Physician 2014;17:E489-501.

7. Manchikanti L, Singh V, Pampati V, Falco FJ, Hirsch JA. Comparison of the efficacy of caudal, interlaminar, and transforaminal epidural injections in managing lumbar disc herniation: is one method superior to the other? Korean J Pain 2015;28:11-21.

8. Manchikanti L, Benyamin RM, Falco FJ, Kaye AD, Hirsch JA. Do epidural injections provide short- and long-term relief for lumbar disc herniation? A systematic review. Clin Orthop Relat Res 2015;473:194056.

9. Ridley MG, Kingsley GH, Gibson T, Grahame R. Outpatient lumbar epidural corticosteroid injection in the management of sciatica. Br J Rheumatol 1988; 27:295-9.

10. Carette S, Leclaire R, Marcoux S, et al. Epidural corticosteroid injections for sciatica due to herniated nucleus pulposus. N Engl J Med 1997;336:1634-40. 